\title{
Some aspects of the notation and performance of German song around 1400
}

The unwavering aspiration of Hugo von Montfort, Count of Bregenz, to high moral pretensions is apparent throughout his poetic works his love songs in the form of versified letters, for example, were intended not for his beloved but for his wife, and the wachter (watchman) of his Tagelieder appears as a personified super-ego who warns the poet ${ }^{1}$

\section{Lieder tichten tu nit mer \\ das rat tch dir by miner er \\ davon man tantzen tut \\ Write no more songs \\ I advise you on my honour. \\ for dancing}

The poet answers

Wachter, des wil tch volgen dir

der lied geticht ich ntemer mir

des solt du sicher sin

Watchman, I will take your advice.

I will not write these songs any longer.

you can be sure of that ${ }^{2}$

Despite this warning, Hugo returned to the despised genre of the dance-song, illustrating the voice of Frau Welt in a dialogue with the allegorical figure of the knight, in whom traditıonal ideals and virtues are symbolized $^{3}$

This dialogue is known from a presentation manuscript of Hugo von Montfort's poetry in Heidelberg (see illus 5 and ex 1) The magnificent miniature with which the entry is decorated explains why the dialogue has become his best-known poem The activitıes of the illuminator. Heinrich Aurhaym, make it possible to date the parchment manuscript from shortly after $1410^{4}$

The poet presents the dialogue in scenes on several levels, comprising content, and-with the help of his 'Knecht' (page) Burk Mangolt-music ${ }^{5}$ A catalogue of knightly virtues, presented in the bar form characteristic of late-medieval Spruch, is set opposite the temptations of Frau Welt For her, Hugo returns to the literary style of the dance-song, as exemplified by the
Ex 1 Hugo von Montfort, 'Fro welt', from D-HEu Cpg 329, f $35 \mathrm{r}$
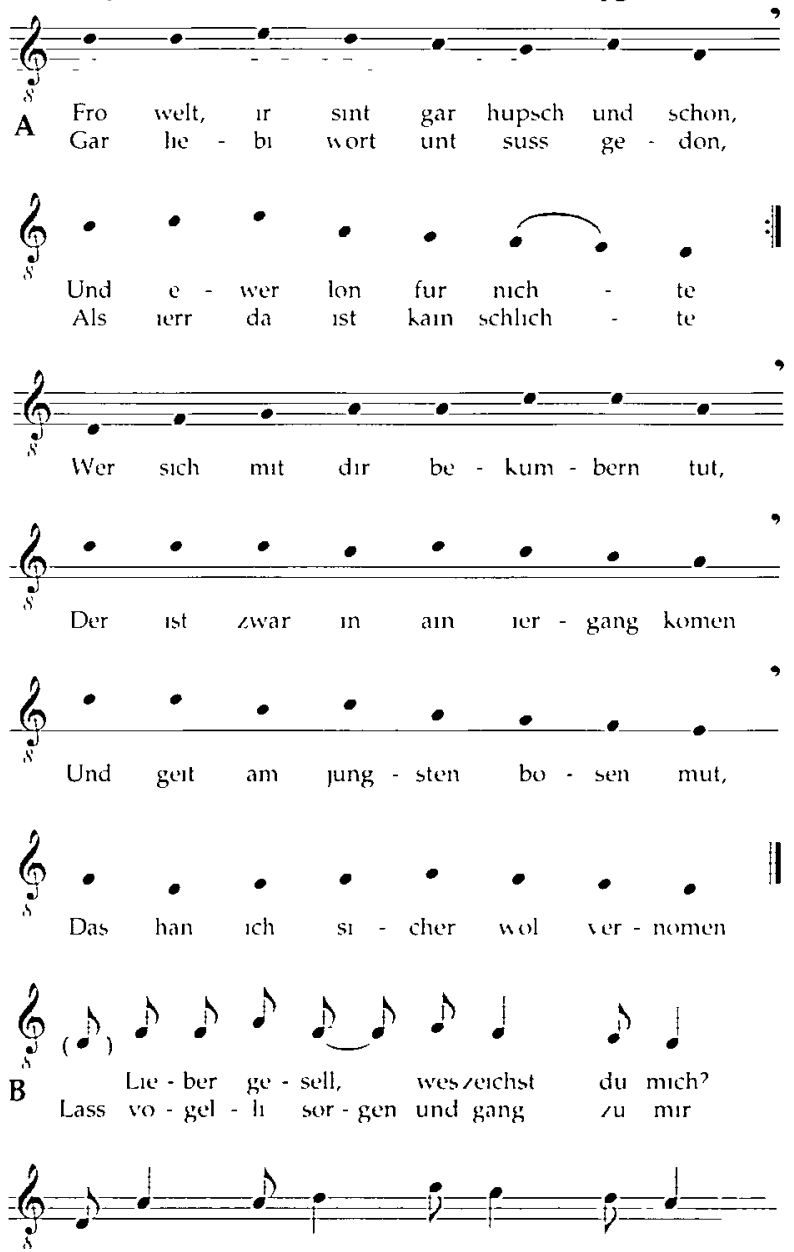

Ich han dir dikch doch mut ge-geben, Undspring mit fro - den an den tants,

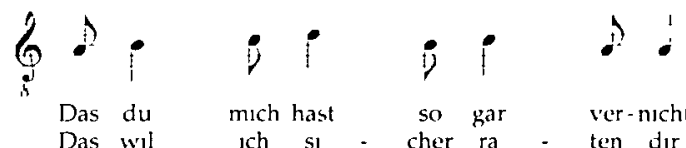

Das wil ich si - cher ra - ten dir

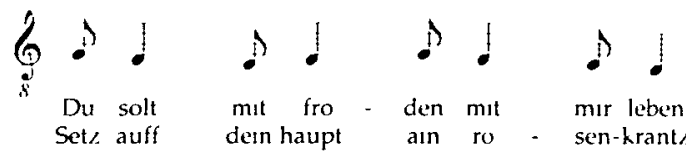



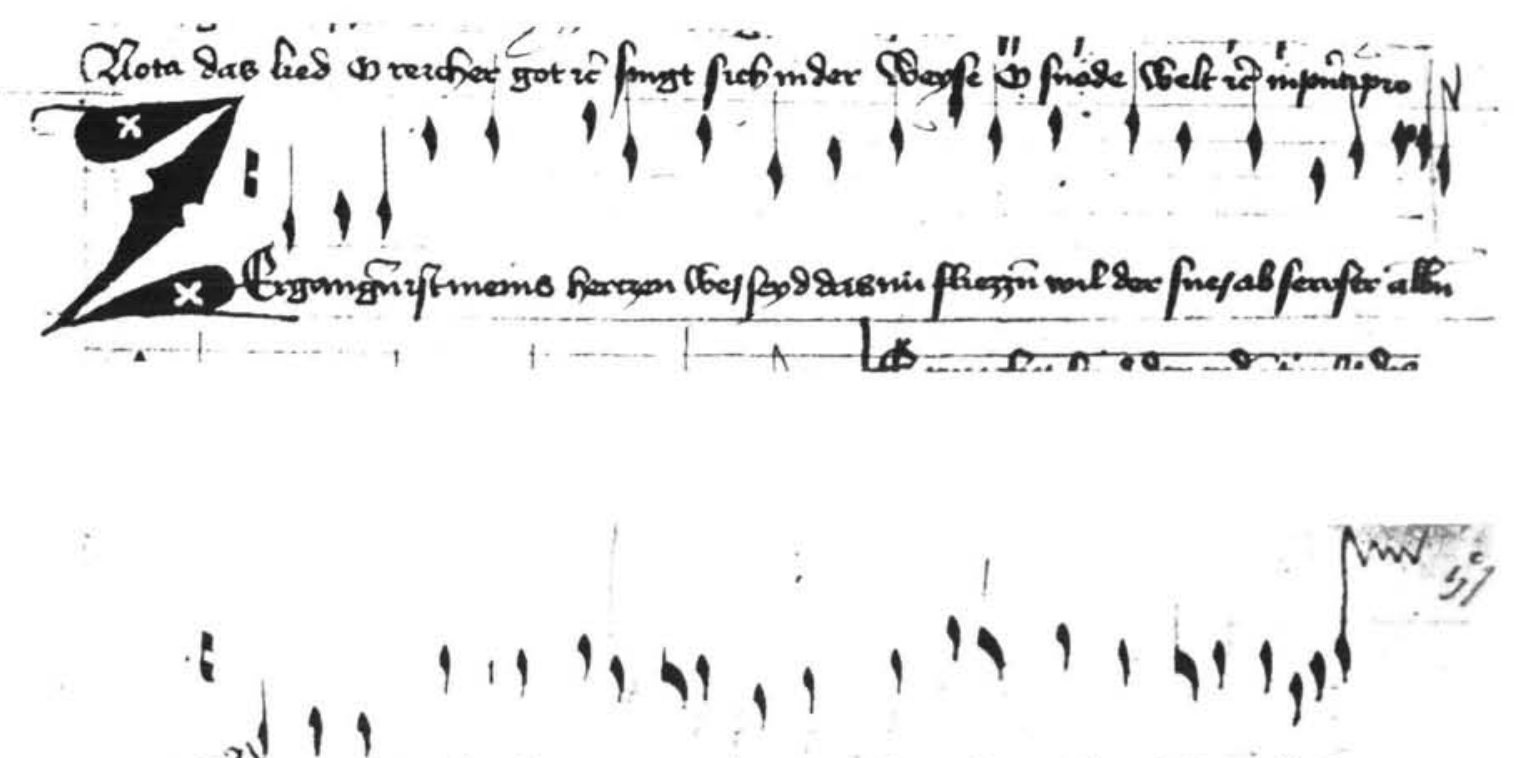

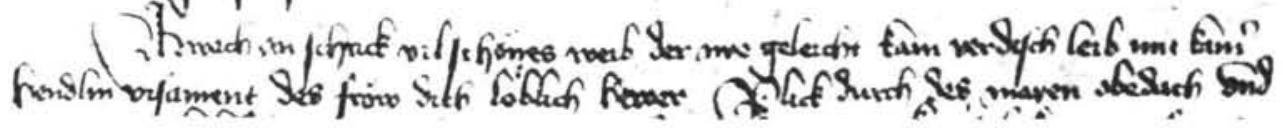

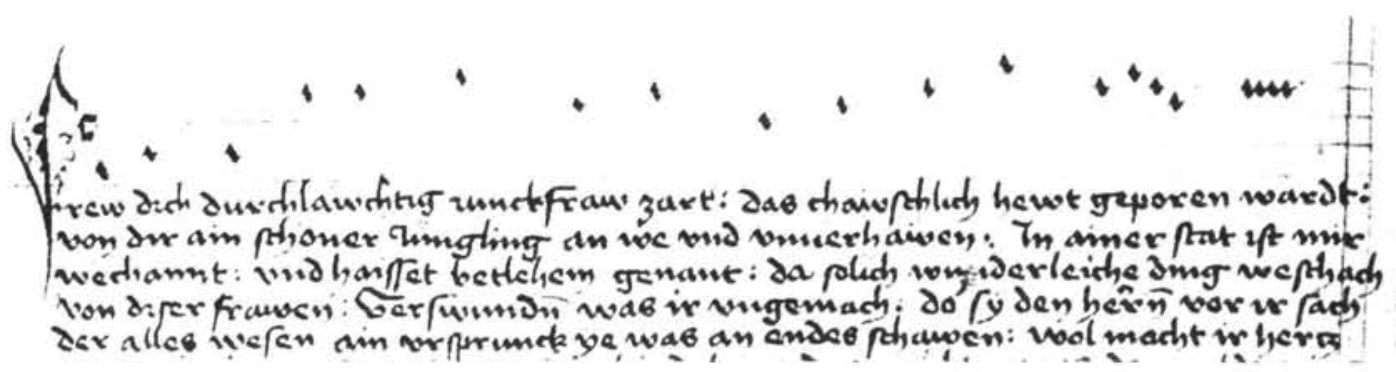

1 Wolkenstein MS A $(A-W n$ 2777). ff 481, 51 r and 561

songs of Neidhart von Reuenthal and his many followers. songs which were still popular and widely known around 1400.

The contrast is underlined by the choice of different musical characteristics: the broad arches of the knight's calmly flowing melody are set against the triadic motifs and melodic leaps that accompany Frau Weit. in a process that helps to elucidate the text:

Luss bugrilt surgen und gang zis mir

und spring mut froeden an den tantz

Let the birds worr and come to me

and fump with fos into dance
Finally-and this is particularly interesting-the contrast is defined further by the use of different kinds of notation: while the knight's speech appears in traditional Gothic chant notation of the Lorraine type. which does not allow for rhythmic differentiation, the dance-song of Frau Welt is copied in an awkward mensural notation that implies an emphatic triple rhythm.

This mensuration is the product of the addition of minim tails to the puncta of the chant notation: the Gothic punctum was clearly now interpreted as a semibreve. But the scribe was uncertain of his task: 
first he placed the tails at random, then he omitted all rhythmic clarification, and only in the fifth verse of the dance-song did he use the tails to imply a regular triple rhythm, yet so cautiously that the minims can hardly be recognized as such.

The process of reinterpreting the Gothic punctum as a mensural semibreve can also be traced in three songs by Oswald von Wolkenstein 'Zergangen 1st meins herzens we' (Kl 116), 'Erwach an schrick' (Kl 40) and 'Frew dich durchlauchtıg iunckfraw zart' (KI 126) ${ }^{6}$ All three were intended to be sung to the same melody, in the manuscript known as Wolkenstein $\mathrm{A}(A-W n 2777)$ only the first is presented with the complete melody, the other two having only an incipit

As can be seen from illus 1, the incipit of the last song consists of a series of pedes muscarum in traditional Gothic chant notation, while that of the second song comprises semibreves interspersed with occasional minims, only in the first song is a regular mixture of semibreves and minims recognizable As in Hugo von Montfort's dialogue, differentiation may be observed here between speech in free rhythm and rhythmic dance-song Both in the songs of didactic and narrative content that are speech-oriented as well as the autobiographical songs and some of the Tagelteder, the succession of identical semibreves points to a free performance governed by the rhythm of the text By contrast, the notation of the dance-like love songs consists of a more or less regular alternation of semibreves and minims, pointing to an accented rhythmic performance

Oswald was also able to combine these two modes of performance The Tagelled 'Es seusst dort her von orient' ( $\mathrm{Kl} \mathrm{20}$ ) suggests that free performance was only envisaged for the two Stollen of the Aufgesang, by contrast, the Abgesang shows the characteristic sem1breve-minım rhythm of the dance-song (see illus 2 and ex 2) Here, as in the works of Hugo von Montfort, the contrast in musical setting reflects the content of the text While description of the situation and of the lovers' dialogue at dawn-traditional subjects of the Tagelied-are elaborated in the Aufgesang, in the Abgesang (designated repeticio) Oswald introduces an element of dramatic action

\section{Zwar si began in drucken \\ zucken aus dem slaff \\ freuntlich an sich smucken. \\ rucken ane straff}

And she began to cuddle,

to bring him out of his sleep. to nestle against him closely,

to press against him with desire

The works of these two poets thus demonstrate that a knowledge of mensural notation made it possible, on one hand, to notate the emphatic rhythmic character of the dance-song, and, on the other, to emphasize the rhythmically free performance of Spruch and related song types The combination of these methods of performance in Hugo's dialogue songs and Oswald's Tagelieder shows how wider notational possibilities could also affect the organization of the text Hugo von Montfort's songs resulted from collaboration with Burk Mangolt, who composed the melodies and was probably also responsible for their copying It is not known whether an experienced assistant worked with Oswald von Wolkenstein in creating the music for his monodies But he certainly looked to earher models in his polyphonic songs, for 15 out of the 37 works attributed to him have so far been identified as contrafacta ${ }^{7}$ Their models were derived partly from the repertory of western polyphony popular in Central Europe in the 14th century, and partly, as has recently been discovered, from Oswald's Burgundian contemporaries From this alone it seems likely that his monodies were not solely his own work either Nevertheless, he must have made use of formulas that originated amongst his acquaintances, a circle of intellectuals interested in music, and familiar on the one hand with traditional idioms of German secular monody, and on the other with the notation of western polyphony

These observations are also relevant with regard to a small group of two-part songs, whose style points to native traditions, but whose notation-to a greater extent than that of the monodies-suggests the influence of western notational practices

More extensive rhythmic differentiation is implied in the song 'Wol auf, wol an, kınd, weıp und man ( $\mathrm{Kl}$ 75), whose notation makes use of both red semibreves and red minıms (see illus 3 and ex 3 ) However, a comparison of the notation in the two Wolkenstein manuscripts, and an examination of the grouping of the various kinds of notes shows that this is not the case, for the red semibreve, which normally implies the value of a mınım, must occasionally be read as having the same value as a black one In addition, there are some black semibreves with the value of mınıms, apparently because the scribe forgot to add tails to the minıms 


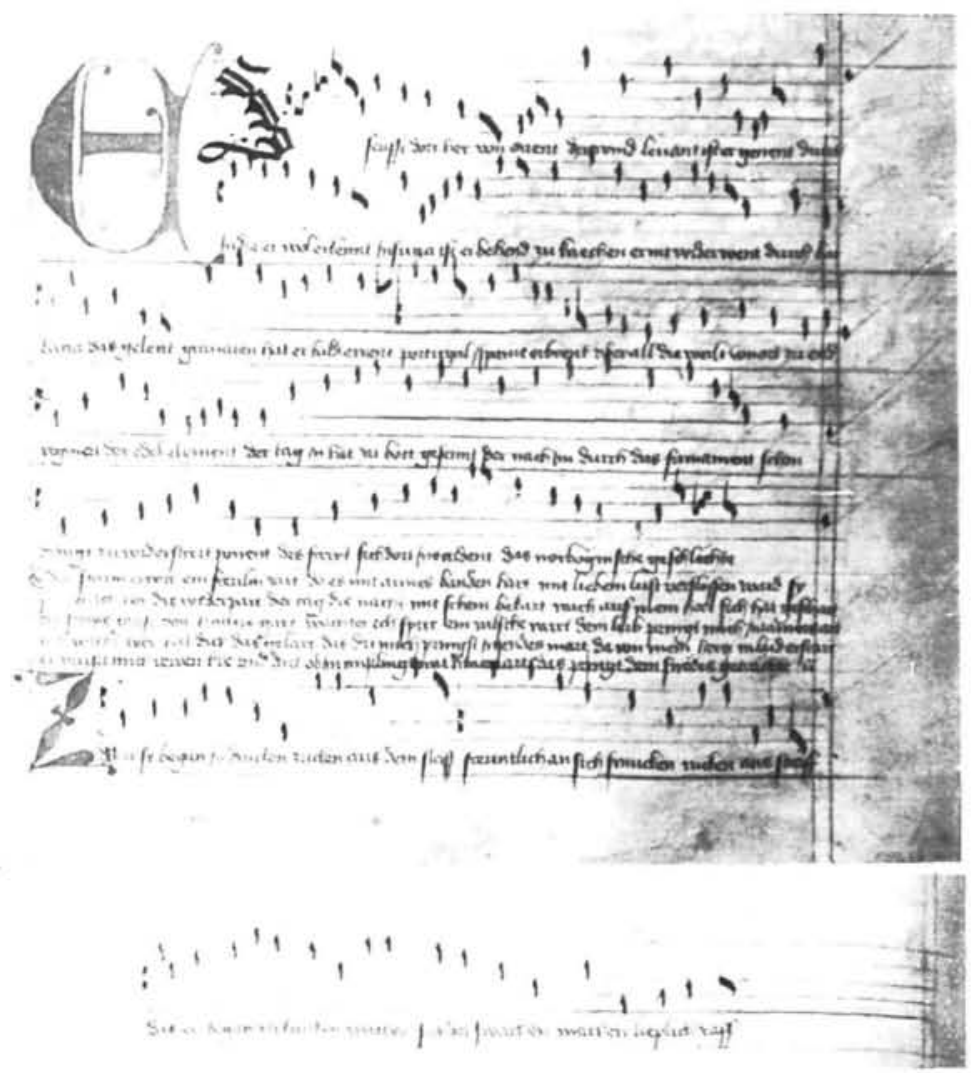

2 Oswald von Wolkenstein. 'Es seusst dort her', from Wolkenstein MS B (A-lu S.S.). ff.9r and v

Concealed behind the seemingly complex notation lies a surprisingly straightforward composition; apart from the beginnings and ends of sections, the upper and lower voices move almost exclusively in parallel fifths. ${ }^{k}$ Here, the practice of 'fifthing: which had formerly not required notation, is fully specified. The rules of this technique, derived from theoretical writings and practical examples, have been described by Sarah Fuller: an upper voice would be improvised in parallel 5 ths to a given melody; and. at the beginning or end of a section. would move from or to the octave or unison."

Oswald himself refers to it (Kl.5):

das zittren swecht mir all gelid owe ist mein gesangk

dasselb quientier ich tag und nacht.

mein tenor ist mit rumpfen wolbedarht.

Shivering weakens $m$ y entire body.

Mr song is called o weh

and 501 sing day and night in fifths:

my Tenor has become fragmented.

and also (K1.21):
Wie wol der gauch von hals nit schon quientieret und der franzoisch hoflich discantieret

Just as the cuckoo does not sing beautifully with fifths in his throat. and sings discant in the french courtly manner.

Hugo von Montfort also refers to it:

Die vogel singen uberal

quint und quart mensur

mit mangem sussen lieben schal

etleicher halt tenur

octaf die stimm erhellen tüt

The birds sing in intervals of fifths or fourths with quite sweet lovely sounds: sometimes one stops the tenor. the octave sounds bright with it

and:

Da hort ich vil der vogel don octav was nicht vergessen ienur und discuntleren "

1 heard much bird song. the octave was not neglected with the tenor and with disrant singing 
Ex.2 Oswald von Wolkenstein. 'Es seusst dort her. transcription from Wolkenstein MS B (A-lu s.s.)

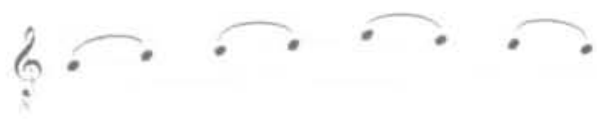

Es seust dort her von $\quad 0 . \mathrm{ri}$. ent
Den sturm or - hort ain freu- lin zart.
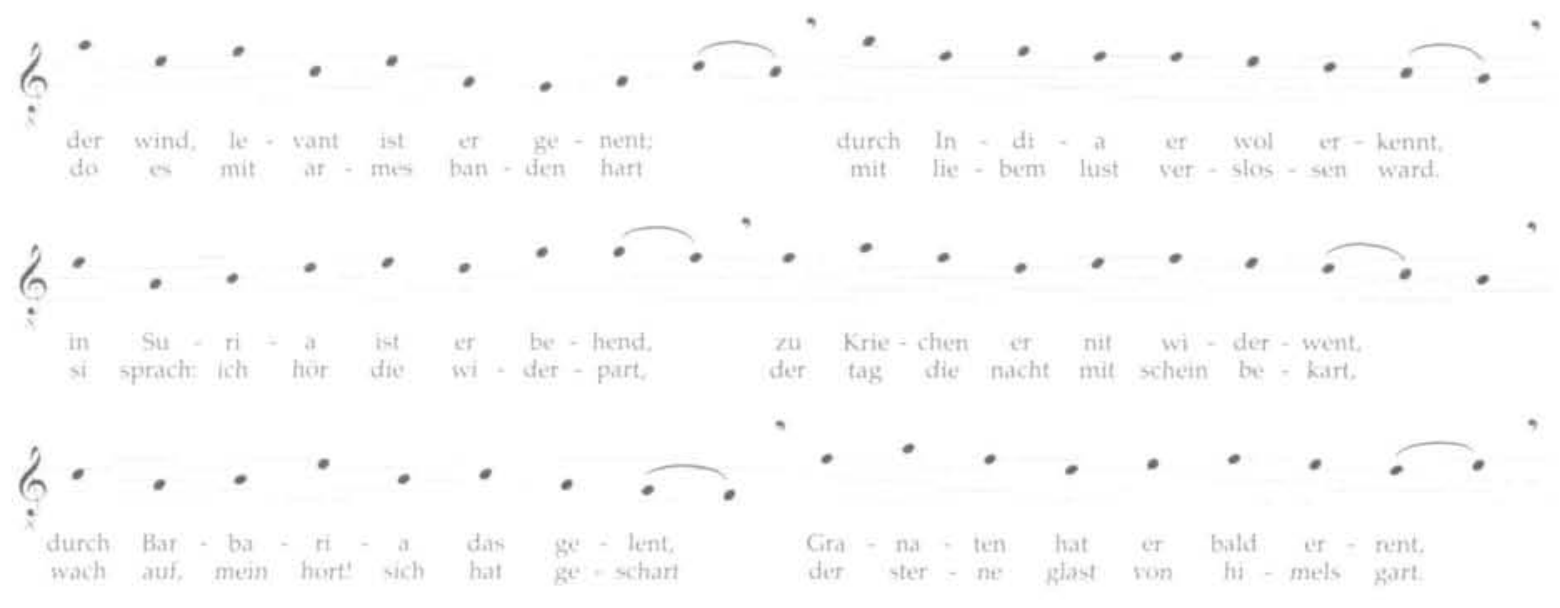

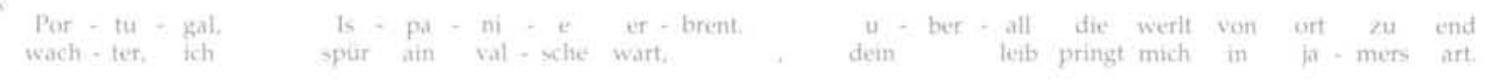
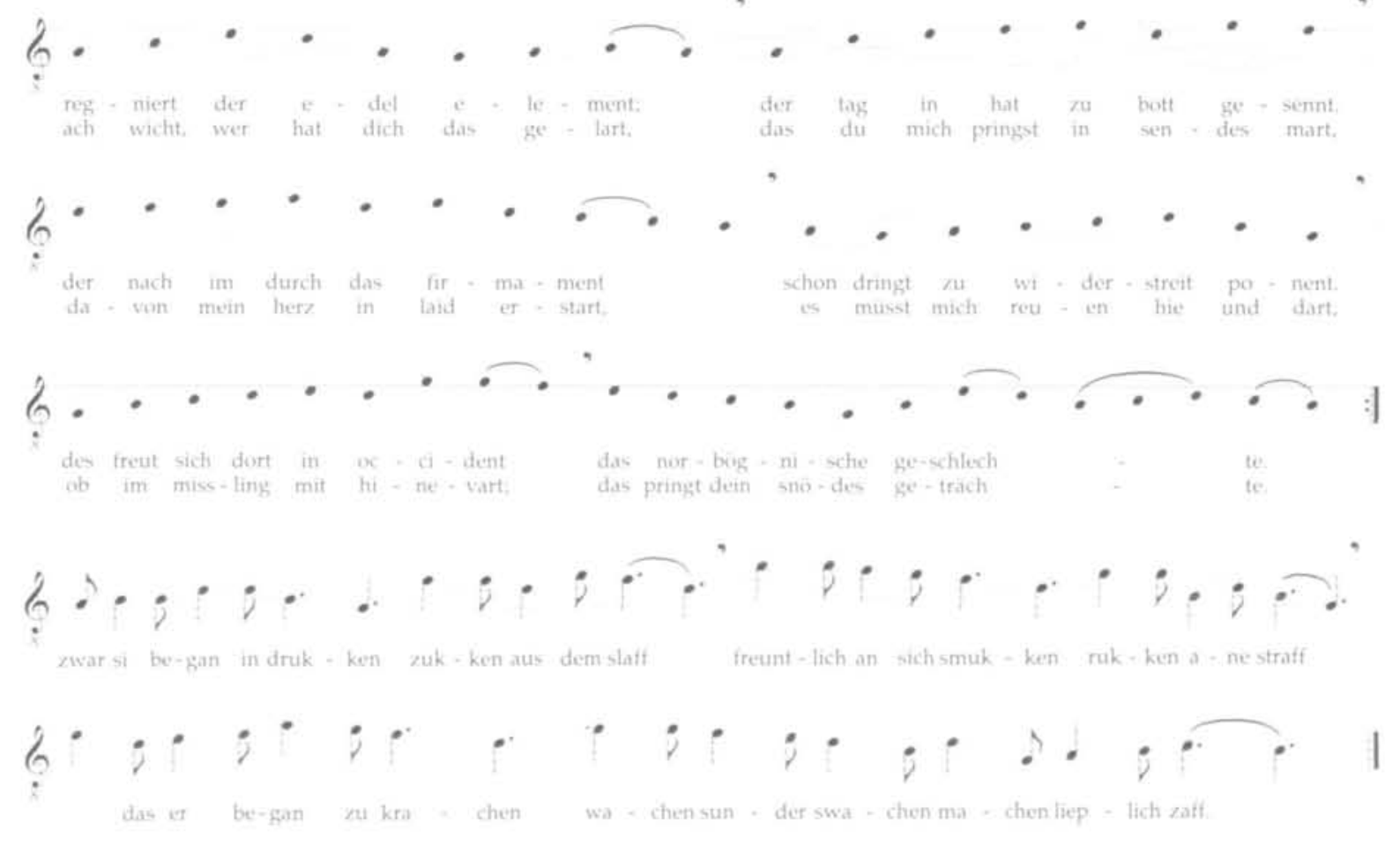

EARLY MUSIC MAY 1990

239 


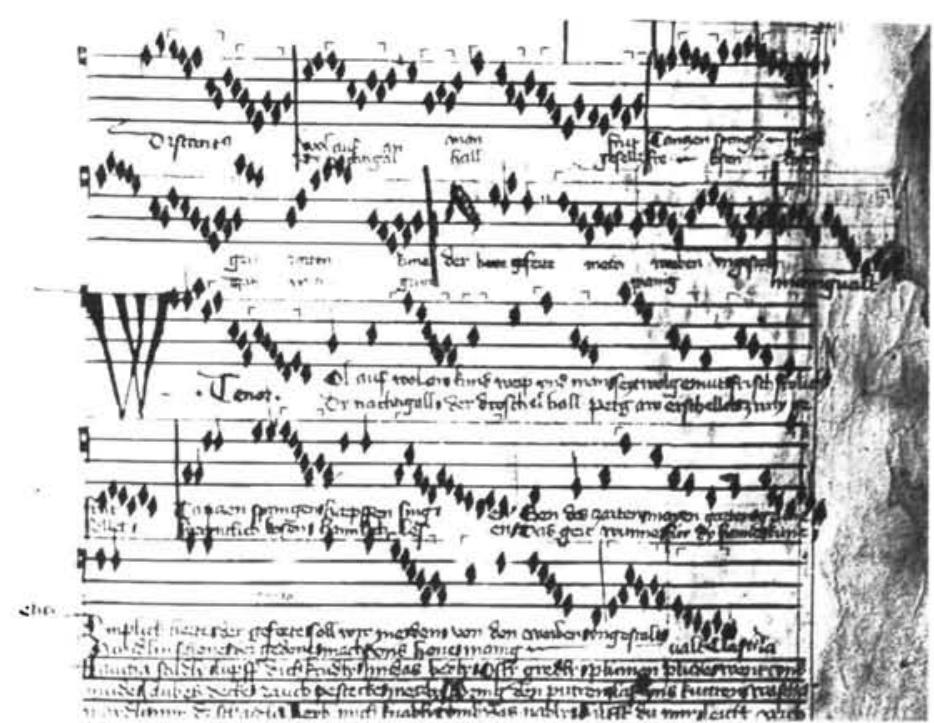

3 Oswaid von Wolkenstein. Woi dui, wol an. from Wolkenstein MS A (A.Wn 2777), 1.35r. Red notes in the MS are marked by $\Gamma$

Improvized polyphony is also suggested in two secular songs by the Monk of Salzburg preserved only in monophonic versions. The Mondsee-Vienna manuscript ( $A \cdot W n$ 2856) contains the following rubrics: 'Der tenor haizt der freudensaal' (This tenor is called 'Der Freudensaal' [the room of joy]) and 'Ain tenor von hubscher melodey, als sy es gern gemacht haben. darauf nicht yglicher kund ubersingen' (A tenor of attractive melody, as they composed it, not everyone can improvize on it)."

Together with the repeated references to Hugo von Montfort and Oswald von Wolkenstein to 'fifthing' and singing in discant, this shows that the polyphonic performance of secular songs preserved as monodies has to be considered. The notation of works that obey the rules of improvized polyphony underlines this conclusion. At the same time the question must also be asked why and under what conditions secular songs were copied out in the form of simple polyphony.

The Monk of Salzburg's Tagelieder 'Dy trumpet' and Ain enpfahen point to a possible explanation. ${ }^{12}$ In the former. which probably owes its name to the continuous triadic motifs in both voices. the dialogue of the lovers in the top voice is juxtaposed with the warning cry of the watchman in the lower voice. In 'Ain enpfahen', the dialogue is shared between the two voices. Double texts are also found in another of the Monk's two-part songs. Wolauff lieben gesellen Sis willekommen her Martin' (the song of Martin). ${ }^{13}$ While this work is preserved in four sources. the Tagelieder appear onl in the Mondsee-Viennd manuscript. the most important source of the Monk's secular output. which Karl Bertau has recently established as dating from the second half of the 15 th century. ${ }^{14}$ An earlier source for all three of the Monk's polyphonic songs, the Strasbourg Codex 222 c. 22 , was destroyed by fire in 1870.

Polytextuality and dialogue structure can only be heid partly responsible for the notation of Oswald's traditional works. The song 'Wol auf, wol an' has alternating texts in bars 23-4; with the tenor reading 'Amplick herte'. and the discant 'der geferte': MS A gives the direction in discantu at this point. ${ }^{\text {is }}$

But another reason for this notation in Oswald's 'simple' pieces could be the composer's or the copyist's desire to impose a sophisticated form on to the improvised examples of an unwritten tradition. a form modelled on that of the international repertory that he knew. But this did not extend to taking over the rules of counterpoint; it applied only to the notation. and only as he understood it or as it caught his eye. that is. particularly in the various uses of red notation.

Comparable. though in a different form. is a twopart work in the so-called St Emmeram Codex. D-Mbs Clm. 14274 (see illus. 4 and ex.4). I have been able to identify its tenor as the so-called 'taghorn'. another Tagelied by the Monk of Salzburg. ${ }^{16}$ The 'taghorn' is preserved elsewhere only in a monophonic version. although a note in the Mondsee-Vienna manuscript seems to suggest a drone accompaniment. The St Emmeram Codex gives the tenor without text. while the discant sets the Latin himn lent rerum conditor. In 
Ex.3 Oswald vo Wolkenstein. 'Wo aud, wo an', transcription from Wolkenstein MS A (AWn 2777) (The C4 signature of the cantus is corrected to $\mathrm{C} 2$.)
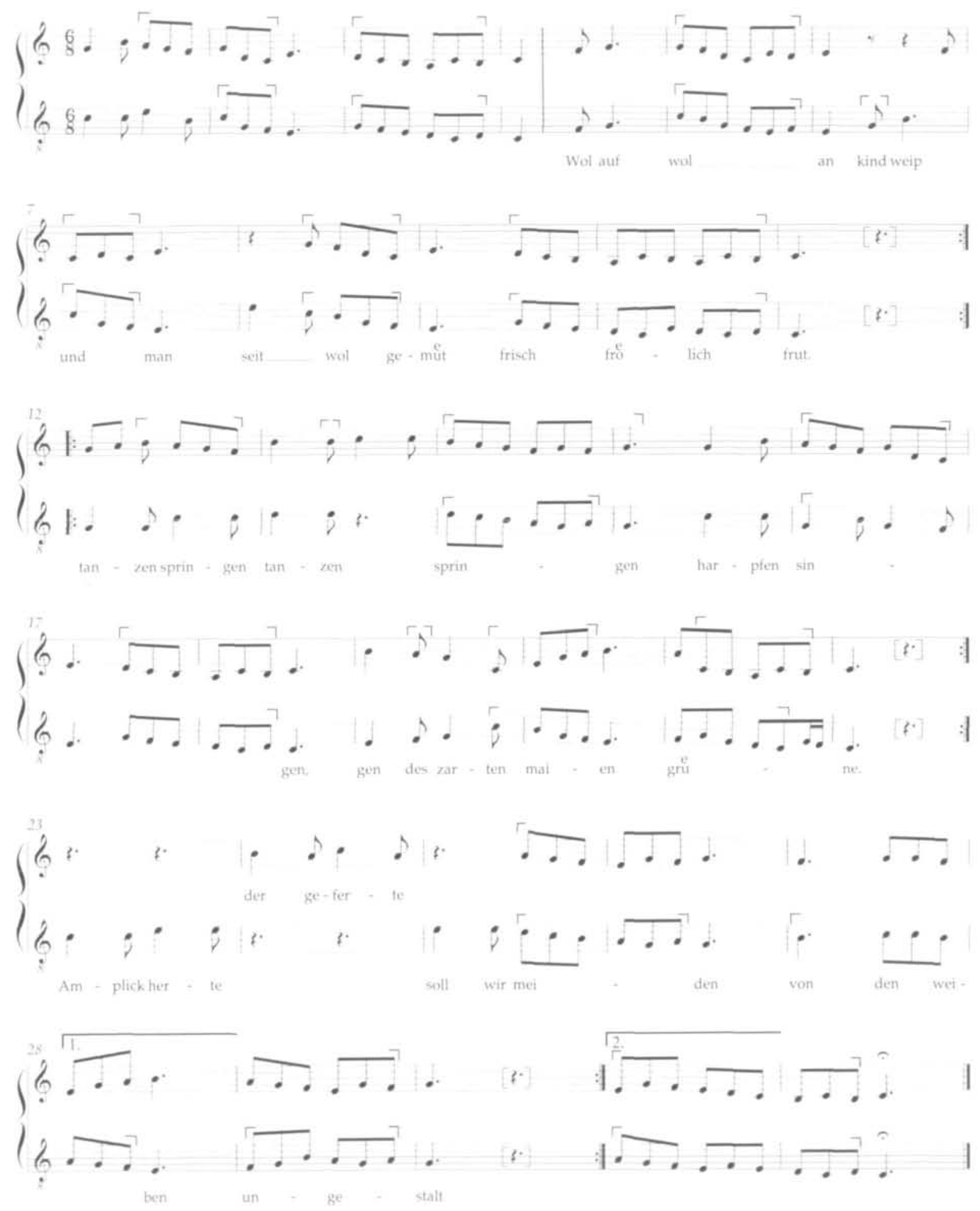

EARLY MUSIC MAY 1990

241 


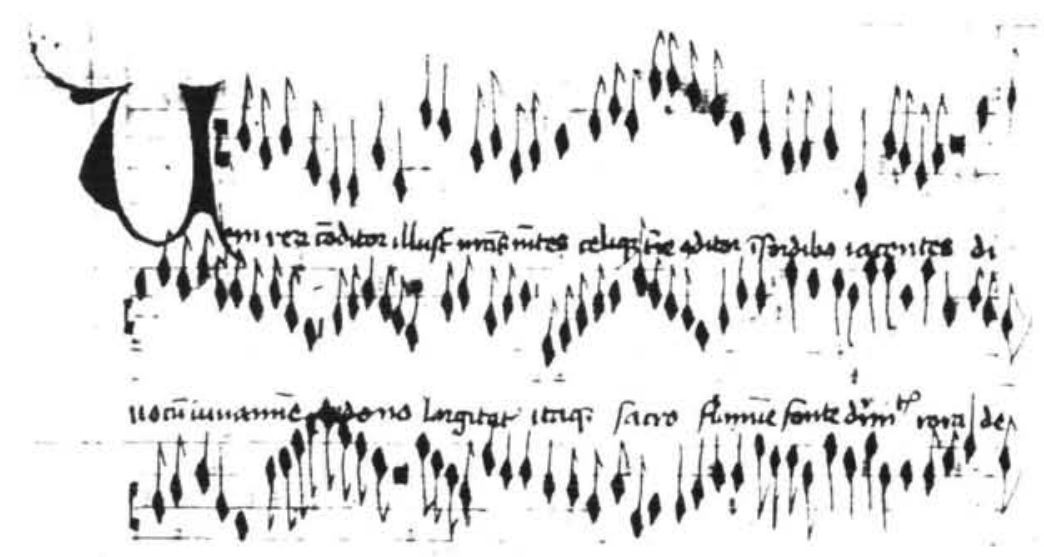

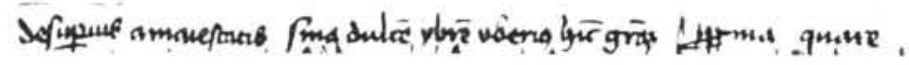

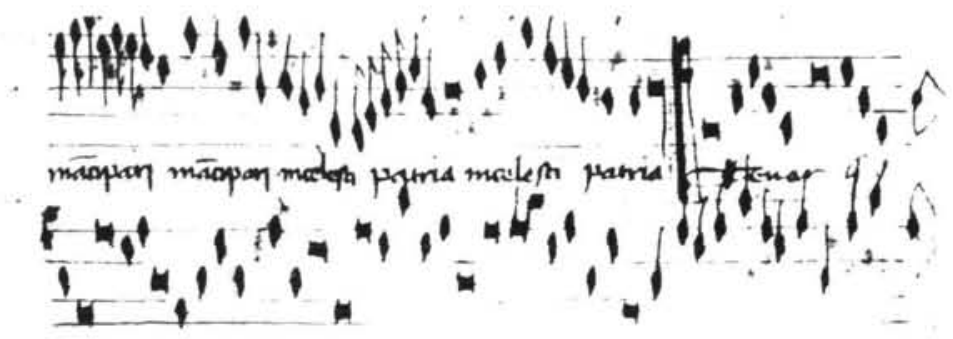

4 'Veni rerum conditor', from St Emmeram Codex (D-Mbs Clm.14274). ff.64v-65r

spite of the rich figuration of the upper voice this clearly constitutes another example of simple polyphony as may be recognized more easily when the work is reduced to its basic framework (see ex.5).

Ex.5 'Veni rerum conditor', reduction

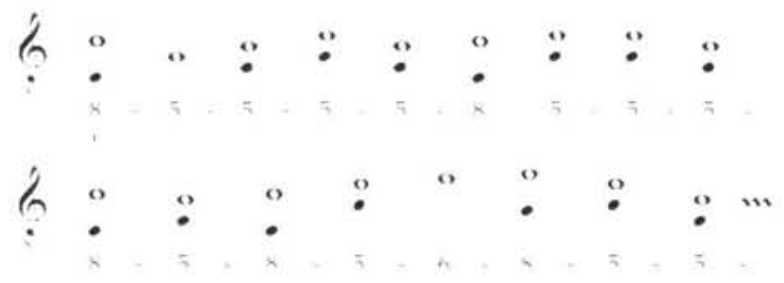

Parallel fifths moving to final octaves again suggest the technique of 'fifthing', but the second section also contains some writing in contrary motion: voice crossing is, however, avoided because the range of the upper voice lies about a fifth higher than that of the tenor. As well as the use of mensural notation and especially of small note-values, the work takes on a sophisticated appearance through the flourishes of the upper voice. The majority of the discant's melodic formulas correspond to those known from early organ tutors. $^{17}$

The copying of both secular monodies and simple polyphony in Oswald and the St Emmeram Codex demonstrates a meeting of local traditions with Ars Nova notation. But is is also apparent that certain circles were more prepared to accept mensural notation than its associated contrapuntal theories. Early 15th-century composers in Central Europe were thus able to use Ars Nova notation for works that looked back to the beginnings of polyphony.

The circumstances in which the traditions of Central Europe and those of the West came to meet may now be examined. The provenance of manuscripts containing regional early 15 th-century songs in modern notation is important. The 'taghorn'. for example, appears in the sixth gathering of the St Emmeram Codex, which, as Ian Rumbold's and Dagmar Braunschweig-Pauli's investigations have shown, must have originated before 1440, at the University of Vienna. ${ }^{18}$ The compiler of the Schratsches Liederbuch. Liebhard Eghenvelder, who also studied in Vienna, copied secular German monodies (including the songs of Neidhart of Reuenthal) in mensural 


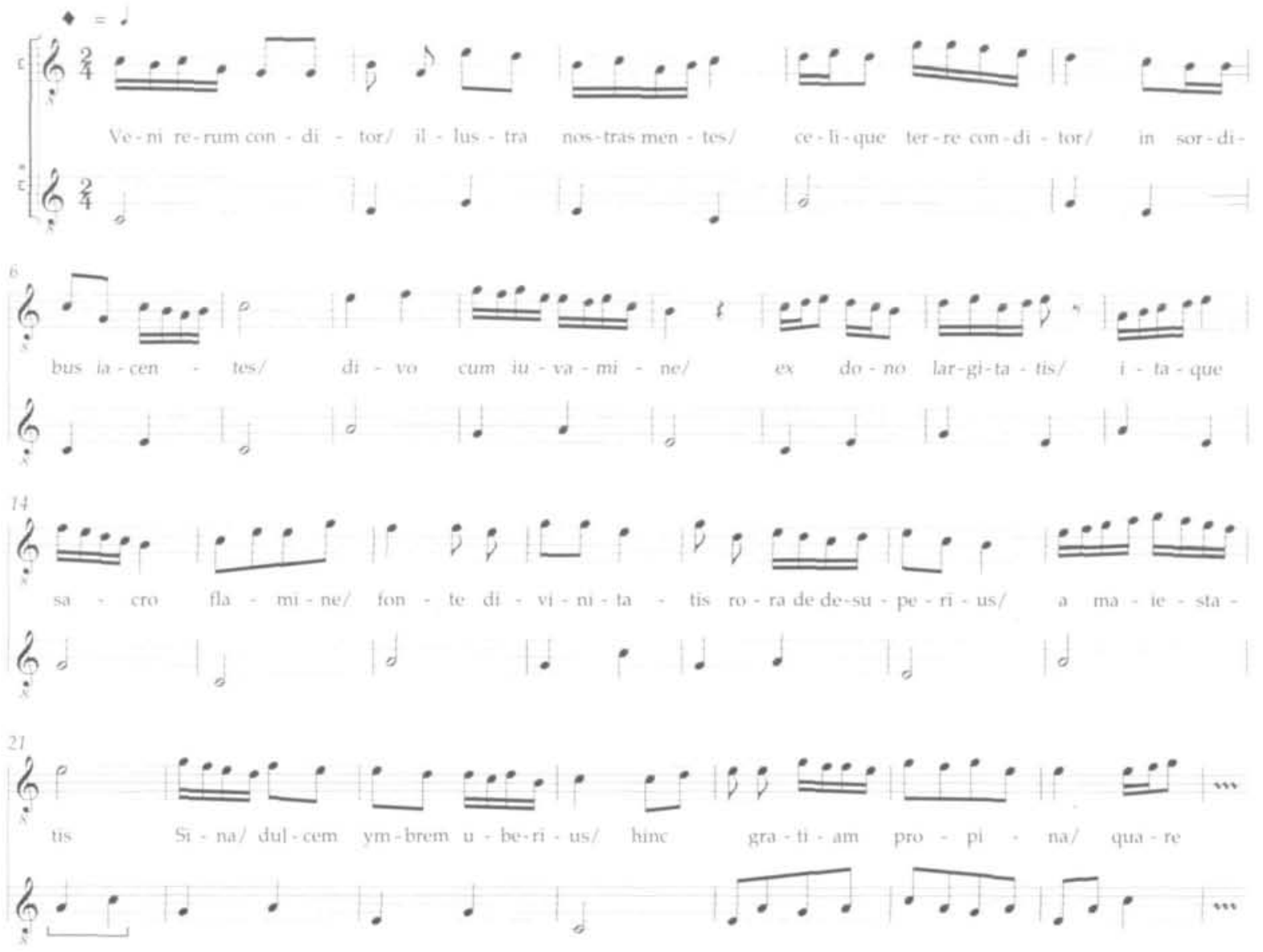

- Ct corrected to C5

notation between 1432 and $1434 .^{19}$ Furthermore, Oswald Holer, the scribe of the sixth gathering of the Wolkenstein MS A, is known to have matriculated in Vienna in $1417 . .^{20}$ Unfortunately nothing is known about the education of Burk Mangold, Hugo von Montfort's musical assistant, unless he can be identified with the Mangoldus studying at the University of Prague in $1378 .{ }^{21}$ Burkhardus Mangolt of Pregantia, listed as matriculating from the University of Vienna in 1450, cannot have been the composer. since the latter died before $1435 .^{22}$

A connection with the University of Heidelberg is suggested by a monophonic version of the 'taghorn' preserved in the former Heidelberg manuscript, $I-R v a t$ Palatini lat.1260. Here the Monk's song is presented (in an appendix to a lecture) in a way that seems to suggest mensural notation. ${ }^{23}$ The transmission of
German songs in mensural notation makes the University environment a likely meeting point for regional and Western traditions.

Other evidence that suggests that the University of Vienna acted as intermediary is to be found in the repertory of the St Emmeram Codex, the fragments in Nuremberg ( $D$-Nst lat.9 and 9a), and in Melk ( $A-M$ Cod.749), all of which show that Ars Nova polyphony was known there. ${ }^{24}$ The notation of three chansons in Vorau ( $A-V$ Cod.380) also supports this theory, since the manuscript, dated $c .1419$. belonged to one of the University's most prominent canon lawyers, Johann Himmel, who served several terms as rector. ${ }^{25}$

Apart from a familiarity with Western compositions. the teaching of mensural theory must also have been of considerable significance for the assimilation of modern notational practices. A series of mensural 
treatises from Central Europe shows that such teaching took place in German-speakıng regions from the second half of the 14th century onwards Certain similarities between some of these treatises have recently been identıfied by Tom Ward, notably the references to a few works from the international repertory that were evidently widely circulated in Central Europe, and secondly, the use of some unusual signs to indicate prolation, also found in manuscripts origınatıng in Central and Eastern Europe ${ }^{26}$ Another treatıse in this group, largely ignored until now, is the so-called Sterzing Miscellaneous MS (Sterzıng/Vipiteno, City Hall, s s) ff $1 r-3 v,{ }^{27}$ a mensural treatise that contains these same unusual prolation signs and refers to 'Je languis', 'Soy tart tempre' and the anonymous ballade 'A discort' whose incipit is used as an example of notation It is noteworthy that this manuscript, whose oldest section dates from $c 1410$, also contains secular German monody in mensural notation, including songs by Neidhart of Reuenthal and the Monk of Salzburg

Although it is highly probable that mensural theory was disseminated in the university environment, there is no unequivocal evidence to that effect, only the anonymous writer of Michaelbeuren mentions the 'studium Pragense' in the colophon. ${ }^{28}$ Even the university curricula give little further assistance. The much-cited Musica Muris which, next to Boethius's Musica, appears comparatively frequently in curricula is not, as has been shown by Gerhardt Pietzsch and more recently by Max Haas, to be equated with the mensural theory of Johannes de Muris on the contrary, only theoretical music was included in the main course of study ${ }^{29}$

Nevertheless, practıcal music must have played a role outside the obligatory lectures that took up only a limited space in the running of late-medieval universities. Consideration must also be made of the exercitia held in the students' bursae or in the private chambers of their masters, during which discussion took place of preparatory subjects such as grammar and introductory logic But the exercitia also covered the subjects of the Quadrivium-algonsmus, computus, proportiones and so on-as Gerhard Ritter has demonstrated, using curricula from the University of Heidelberg ${ }^{30}$ Practical music, including contrapuntal and mensural theory, can be included under the heading proportiones, for example. The treatise by Henricus of Zeelandia also begins in this way: 'Gaudent musicorum discıpulı, quod Henricus de Zeelandıa alıqua brevıa tractat de musica: videlicet quid sint proportiones et in quo fuerint ${ }^{31}$ I have been able to identify a Hinricus de Zelandia from the dıocese of Cambral as having been at the University of Heidelberg in $1429^{32}$

Finally, the musical training at Heldelberg is possibly reflected in two treatıses written by a former student there, Albertus Loffler, who later became a Dominican prior in Basel One is a commentary on Hugo Spechtshart von Reutlingen's Flores musicae, beginning 'Quoniam ut dicit Sanctus Augustinus in domo Dei', and the other a mensural treatise, 'Notandum est circa figuraciones notularum' ${ }^{33}$ Both were also included in the now destroyed manuscript Strasbourg 222c 22, the mensural treatise formed part of the Liber musicalium attributed to Philippe de Vitry ${ }^{34}$

Some conclusions may now be drawn from the foregoing material (1) The experience of mensural notation gained from the university environment made it possible in the 15 th century for scribes of German songs to differentiate in their copying between the performance of lyrics and of dancesongs. (2) Collaboration with a musician or a scribe educated in notation gave the poet the possibility of combining metrical and non-metrical elements in a song (3) The use of Ars Nova notation for simple polyphony led to the copying of songs formerly improvised or transmitted orally (4) Both this and certain observations made by poets demonstrate the possibility of polyphonic performance of monophonıc songs

Simple polyphonic songs in Ars Nova notation marked only the first step in the assimilation of western polyphony in Central Europe, a step that, in the end, bore no consequences What did bear fruit, however, was a further step that resulted in the production of works indigenous to German-speaking areas by the contemporaries of Dufay, thereby leading to the songs found in the Lochamer and Schedel collections

Translated by Barbara Haggh

Lorenz Welker studied medicine in Muntch and mustcology and psychology in Basle and Zunch He is an assistant lecturer at the Musikwissenschaftliches Seminar. University of Heidelberg

\footnotetext{
${ }^{1}$ Concerning Hugo von Montfort, see B Wachinger. 'Hugo von Montfort, Die deutsche Literatur des Mittelalters Verfasserlextkon (Berlın, 2/1982), iv, pp 243-51, and the more recent contributions in F V Spechtler et al. Einfuhrung zum Faksimile des Codex Palatinus
} 


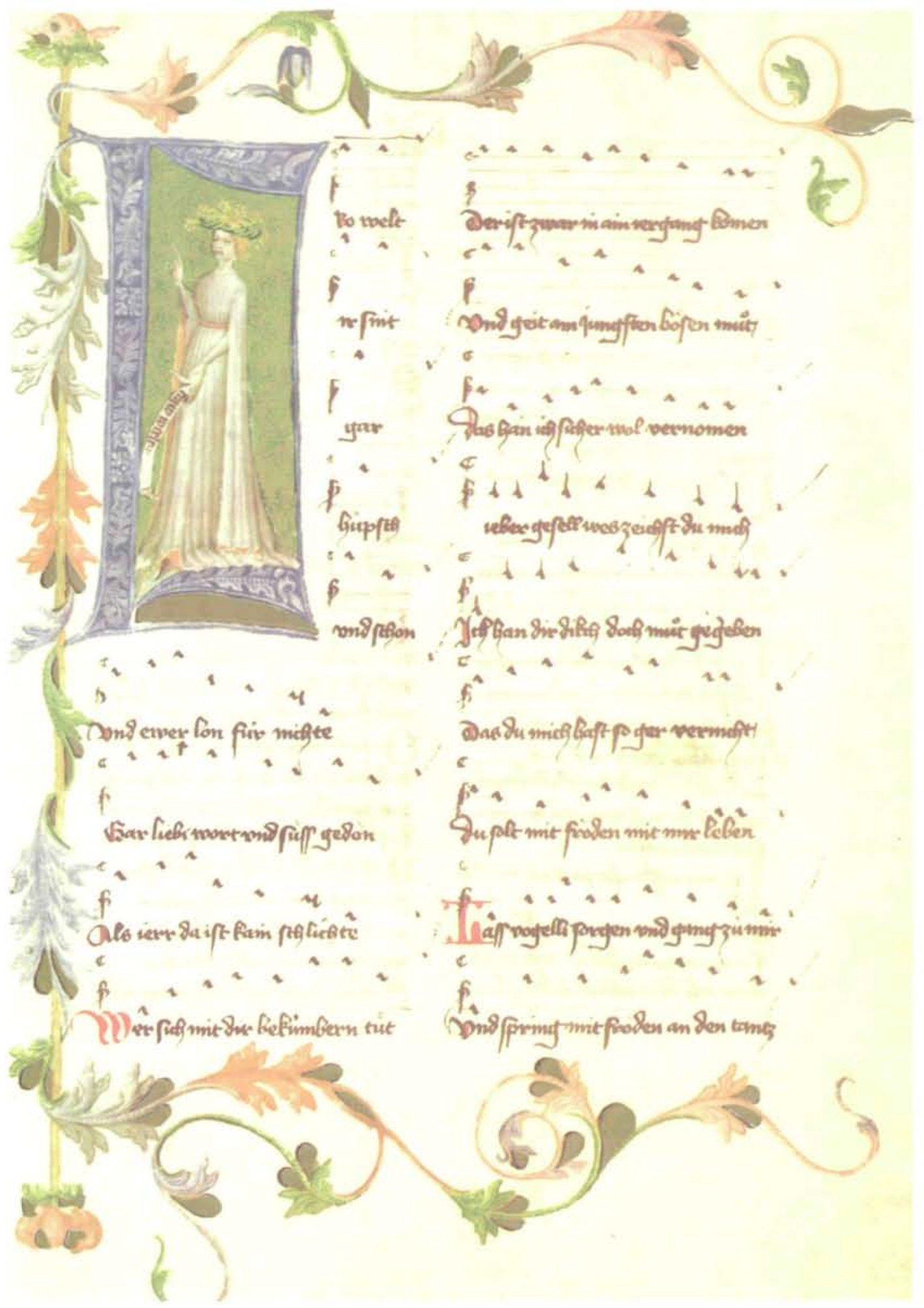

5 Hugo von Montfort, 'Fro welt' from D-HEu Cpg.329, f.35r 
Germanicus 329 der Universitatsbibhothek Heidelberg (Wiesbaden, 1990). in press For the songs of Hugo, see Hugo von Montfor II Die Texte und Melodien der Hetdelberger Handschnft cpg 329 transcr F V Spechtler, Litterae, lviı (Goppingen, 1978)

${ }^{2}$ Hugo von Montfort, ed Spechtler, op ctt, no 11

${ }^{3}$ Idem, no 29 A textual-histoncal interpretation has recently been offered by 1 Bennewitz-Behr, " "Fro welt ir sint gar hupsch und schon "Die 'Frau Welt' Lieder der Handschriften mgf 779 und cpg 329', Jahrbuch der Oswald von Wolkensteingesellschaft , iv (1986/ 7). pp 117-36

${ }^{4} D-H E u$ Cpg 329, f 35r- $v$, cf facs ed E Thurnher, F V Spechtler and $U$ Muller, eds, Hugo von Montfor I Die Hetdelberger Handschnfi cpg 329 und die gesamte Streubberhefening. Litterae, lv1 (Goppıngen, 1978), and E M Vetter in Spechtler et al, Einfuhrung, op ctt

${ }^{5}$ On Burk Mangolt see B Kippenberg and D Fallows, 'Mangolt, Burk' in $N G$, and $\mathrm{L}$ Welker. 'Die Melodien des Burkhard Mangolt' in Spechtler et al. Einfuhrung, op cit

${ }^{6}$ The numbering of Oswald's songs follows K K Klein, Die Lieder Oswalds von Wolkenstem. Altdeutsche Textbibliothek. Iv (Tubingen. 2/1975)

${ }^{7}$ See I Pelnar, Die mehrstımmigen Lieder Oswalds von Wolkenstein, Munchner Veroffentlıchungen zur Musıkgeschıchte, xxxı (Tutzıng, 1982). and L Welker, 'New Light on Oswald von Wolkenstein Central European Traditions and Burgundian Polyphony", Early Mustc History [EMH], vil (1987), pp 187-226, and D Fallows. 'Two Equal Voices A French Song Repertory with Music for Two More Works of Oswald von Wolkensteın', EMH, vı (1987), pp 227-41

${ }^{8}$ For another interpretation, see I Pelnar, Die mehrstimmigen Lieder Oswalds von Wolkenstem Edition, Munchner Editıonen zur Musıgeschıchte, 11 (Tutzıng, 1981), pp 24-7

${ }^{9} \mathrm{~S}$ Fuller, 'Discant and the Theory of Fifthıng', Acta Musicologica, 1 (1978). pp 241-75

${ }^{10}$ Hugo von Montfort, songs nos 16 and 28

${ }^{11} A-W n 2856$ (Mondsee-Wiener Liederhandschrift), ff $190 r-v$, cf $\mathrm{E}$ Ferand, Die Improvisation in der Musth (Zurich, 1938), pp 141-2

${ }^{12} A-W n 2856$, ff $188 v-9 r$

${ }^{13}$ See $H$ Brunner. $H$ Ganser. K B Hartmann, 'Das Windsheımer Fragment einer Musikhandschrift des 15 Jahrhunderts', Jahrbuch der Oswald von Wolkenstem Gesellschaft, 1 (1980/1), pp 185-222

${ }^{14} \mathrm{H}$ Heger, ed, Die Mondsee-Wiener Liederhandschrift, facs (Graz, 1968). K H Bertau, review of $\mathrm{H}$ Heger, ed, Die Mondsee-Wiener Ltederhandschnft. in Anzetger fur deutsches Altertum und deutsche Literatur, 1xxxv1 (1975). pp 12-20

${ }^{15}$ This is sımılar to Oswald's song 'Sım Gredlı. Gret' (K1 77) See Pelnar, op ctt. pp 32-5

${ }^{16} \mathrm{~L}$ Welker. 'Das Taghorn des Monchs von Salzburg Zur fruhen Mehrstımmıgkeıt im deutschen Lıed', Schweizer Jahrbuch fur Musikwissenschaft Neue Folge, iv (1984), pp 41-61 (Incl complete transcr)

${ }^{17}$ See T Gollner, Formen fruher Mehrstımmigkett in deutschen Handschnften des spaten Mittelalters, Munchner Veroffentlichungen zur Musıkgeschichte, vi (Tutzing, 1961), pp 181

${ }^{18}$ I Rumbold, "The Compilation and Ownership of the "St Emmeram' Codex (Munich. Bayerische Staatsbibliothek. Clm 14274)', EMH, 11 (1982), pp 161-237, and D Braunschwerg-Paul,, Studien zum sog Codex St Emmeram Entstehung, Datierung und Besitzer ', Kirchenmusikalisches Jahrbuch, lxvı (1982), pp 1-48

${ }^{19} \mathrm{H}$ Lomnitzer, 'Eghenvelder. Liebhard', Die deutsche Literatur des Mittelalters Verfasserlextkon (Berlın, 2/1980), 11, pp 377-9

${ }^{20} \mathrm{~F}$ Delbono, Oswald von Wolkenstem, Handschnft A, Vollstandige Faksimile-Ausgabe (Graz, 1977), pp 38-9 and p 43, ed L Santufaller. Die Matrkel der Universitat Wien (Graz, 1956). 1. p 116

${ }^{2} \mathrm{~J}$ Triska, Repertonum btographicum universitatis Pragensis praehussiticae (Prague, 1981), p 348

${ }^{22}$ Santifaller, Matnkel, op ctt, p 277, Welker, 'Die Melodien', op cit

${ }^{23} \mathrm{H}$ Noack, Der Monch von Salzburg (diss, U of Breslau, 1941), p 80, L Schuba, Die medizintschen Handschnften der Codices Palattr. Latım in der Vatikanischen Btbliothek (Wiesbaden, 1981), pp 3181 Welker, 'Das Taghorn', op ct

${ }^{24} \mathrm{R}$ Strohm, 'Native and Foreign Polyphony in Late Medieva Austria', Musica Disciplina, xxxvı11 (1984). pp 205-30

${ }^{25}$ See Welker, 'Das Taghom', op ctt, and Dte deutsche Ltteratur de. Mittelalters Verfasserlexikon (Berlın, 2/1982/3), Iv, pp 24-7

${ }^{26} \mathrm{~T}$ R Ward, 'A Central European Repertory in Munich, Bayerıschı Staatsbiblıothek, Clm 14274', EMH, 1 (1981), pp 325-43

${ }^{27} \mathrm{Cf} \mathrm{E}$ Thurnher and $\mathrm{M}$ Zımmermann, eds, Die Sterzinge Miszellaneen-Handschnft, facs ed. Litterae, lxı (Goppingen, 1979) for general comments on the MS, see M Zimmermann, Die Sterzinge Miszellaneen-Handschnft. Innsbrucker Beltrage zur Kulturwissen schaft, Germanıstısche Reihe, vi11 (Innsbruck, 1980), on the treatıse see Welker, 'New Light on Oswald von Wolkensteın', op cit

${ }^{28} \mathrm{R}$ Federfofer-Konigs, 'Ein anonymer Musıktraktat aus de: zweiten Halfte des 14 Jahrhunderts in der Stıftsbibliothel Michaelbeuern/Salzburg', Kirchenmustkalisches Jahrbuch, xlvi (1962) pp 43-60

${ }^{29} \mathrm{G}$ Pietzsch, Zur Pflege der Musik an den deutschen Unversitaten bu zur Mitte des 16 Jahrhunderts (Darmstadt, 1971), M Haas, 'Studien zuı mittelalterlıchen Musıklehre I Eıne Ubersıcht uber die Musıklehre im Kontext der Philosophie des 13 und fruhen 14 Jahrhunderts' Forum Mustcologicum 111 (1982). pp 323-456

${ }^{30} \mathrm{G}$ Ritter, Die Hetdelberger Universitat Ein Stuck deutsche: Geschichte (Herdelberg, 1936), 1, pp 171-2 and p 508

${ }^{3} \mathrm{E}$ de Coussemaker, ed, Scnptorum de musica medn aevi novam $\mathrm{c}$ Gerbertina alteram (Paris, 1869), 111, pp 113-5

${ }^{32} \mathrm{G}$ Toepke. ed . Die Matmkel der Universitat Herdelberg (He1delberg 1884), 1, p 181

${ }^{33} \mathrm{CH}-\mathrm{Bu}$ MS F VIII 16, ff $156 r-184 r$ and $184 v-187 v$ on Albertus Loffler, see P Schmidt, 'Die Biblıothek des ehemalıgen Domınıkanerklosters in Basel', Basler Zeitschrft fur Geschichte und Altertumskunde, xv111 (1919). pp 160-254

${ }^{34} \mathrm{~L}$ Welker, Untersuchungen $z u$ den Traktaten der Handschnfi Strasbourg, Bibhotheque municipale, 222 C 22 (diss , U of Zurich, 1988) pp 34-41 Unfortunately, when preparing this article I had not seen the article by $M$ Staehelın, 'Bemerkungen zum verbrannten Manuskrupt Straßburg M 222 C 22'. Die Musikforschung, xlı (1989). pp 2-20 The author presents the above identification of the Basle and Strasbourg treatises However, his conclusions differ from those advanced in my dissertation

\section{Early Music has moved}

The editorial office is now at

7-8 Hatherley Street, London SWIP 2QT

Phone 071-233 5466

Fax 071-233 6638 


\section{FRANS BRÜGGEN Orchestra of the $18^{\text {th }}$ Century}

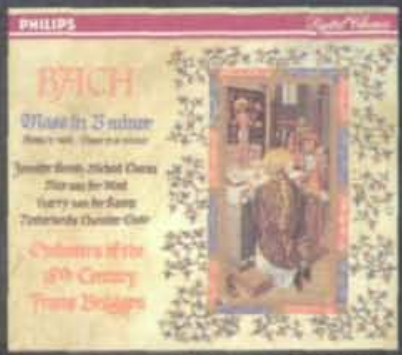

New release: BACH CD 426 238-2

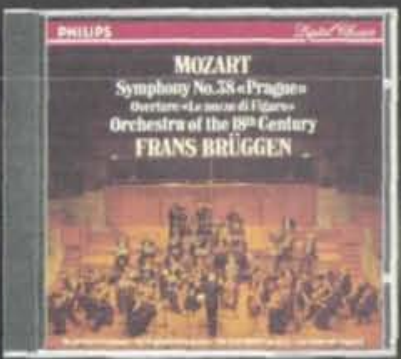

Also released:

Mozart CD 426 231-2

Already released:

Symphonies No. 31, "Paris" 8 No. 35, "Haffner" CD 416490.2

Symphony No. 41, "Jupiter" Overture "La clemenza di Tito"

CD $420241-2$

Serenade "Gran partita" CD $422338-2$

Clarinet Concerto

Clarinet Quintet

Eric Hoeprich

CD $420242 \cdot 2$

Piano Concertos No. 20 8. No. 24

John Gibbons CD 420823.2

Symphony No. 40 \& Beethoven: Symphony No. 1, Op. 21 CD 416329.2

Symphony No. 39 8 Beethoven: Symphony

No. 2

CO $422389-2$
Fo. dart ils of all Frans Brüggen's outstanding recordings on $\mathrm{k}$ - $\mathrm{s}$ Classics, please write for a full colour catalog to: Philips Classics, 1 Sussex Place, London W6 9XS 


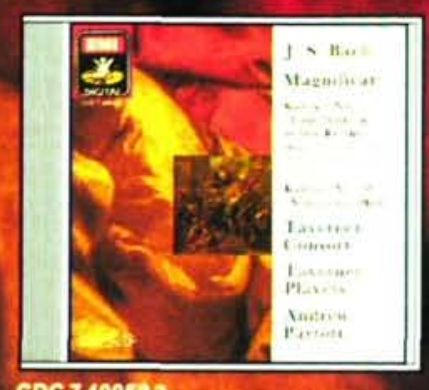

coc7 4995) 2

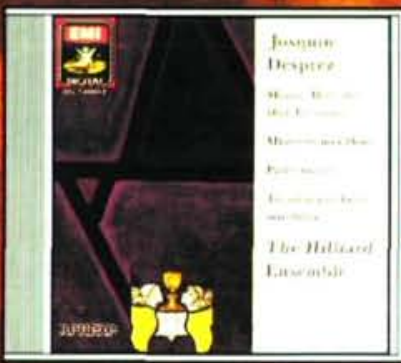

CDC 7499602

\section{New historical}

\section{recordings from}

\section{EMI Reflexe}

Bach

Magnificat

(iantata Nr. I)

- Jaber (

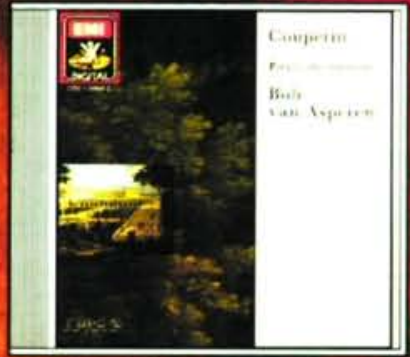

coc 7498452

Cantata No, il) Dun al das $\mathrm{H}_{1-11}$

Täerner Consort

Taverner Players

Andrew Parrott

CDC 7499592

\section{Couperin}

Pièces de clavecin

Bob van Asperen

CDC 7499452

Josquin Desprez

Missat Hertule Dou Fetrariale

Misereremei Deus

Pater mester

Tu sulus quit fac is miralibli.s

The Hilliard Ensemble CDC 7499602

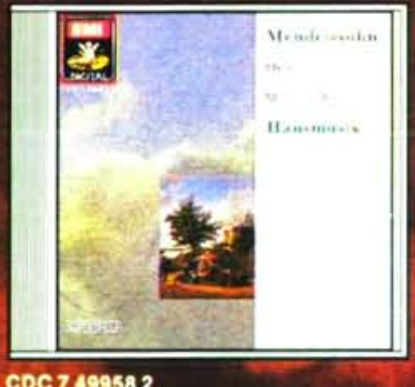

CDC7 499582

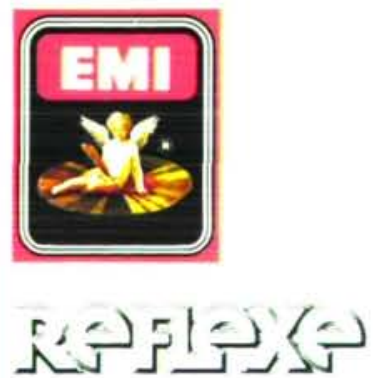


Roger Norrington \& London Classical

\section{Players}

Exclusively on

EMI Reflexe

Beethoven

Piano Concerto No. 5

'Emperor'

Choral Fantasia

Melvyn Tan (Fortepiano)

The Schutz. Choir of London

CDC 749965 1/2/4

Schubert

Symphony No. 9

CDC 749949 1/2/4

Early Romantic Overtures Berlioz $\cdot$ Mendelssohn Schubert - Schumann Wagner. Weber CDC $7498891 / 2 / 4$

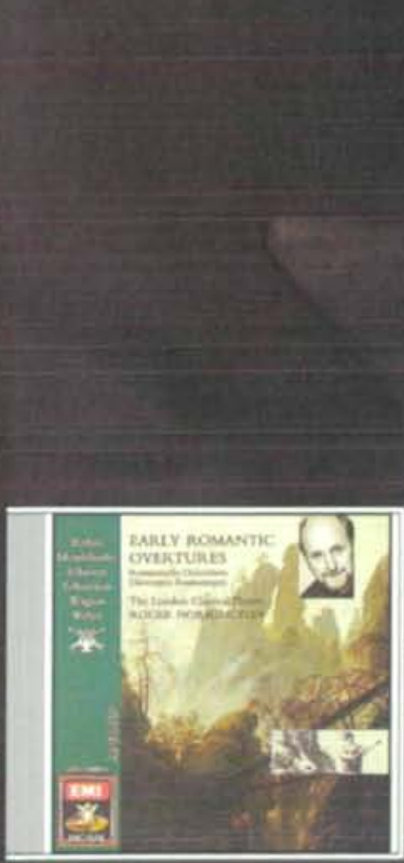

Dी $51=5$

Tourder your free capy of the full

colour Reflexe CD catalogue

please write post free to:

EMI Reflexe CD Caralogue

EMII Record:

Freepost 13

LONDONWIE 2L.P

or telephane $01+887+4+2(9.30 \mathrm{am}-4.30 \mathrm{pm})$

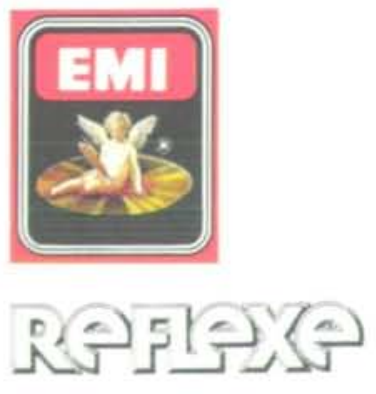




\section{The Early OrCusic Shop \\ I NSTRUMENT K I T S}

Clavichord

The Early Music Shop has over 40 different Musical Instrument Kits to choose from. One of the most popular is the Clavichord. The Clavichord Kit is designed by John Barnes following a fretted clavichord, $\mathrm{cl} 740$, in the Gemeente Museum, The Hague, Holland.

The kit uses solid wood throughout and has a particularly pleasing tone combined with excellent dynamic range.

Disposition: 53 notes CC-e $\mathrm{e}^{\prime \prime}$ Length $44^{\prime \prime}(113 \mathrm{~cm})$ Width $14^{\prime \prime}(36 \mathrm{~cm})$

Depth 4" $(10 \mathrm{~cm})$ Optional lid kit and stand kit available.
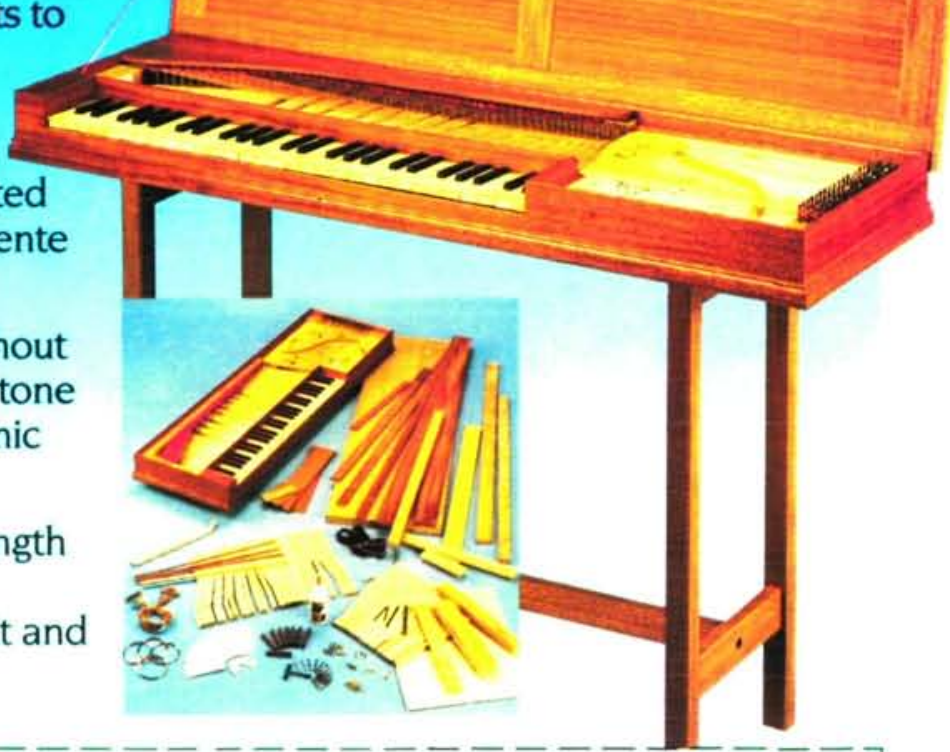

The Tarly Orousic Shop

Main Showroom. Sales and Postal Service

Dept EM., 38 Manningham Lane,

Bradford. West Yorkshire BD1 3EA. England. Tel: (0274) 393753.

Please send me by return of post a colour leaflet free of charge of the

Z Clavichord Kit $\square$ General Kit Leaflet (Black \& White)
Cembalino Kit $\square$ Ottavino Spinet Kit
2 ' Portative Kit OR send $£ 3.00$ for our latest 60
IPlease Tick)
NAME colour catalogue
ADDRESS

ALSO FROM THE EARLY MUSIC SHOP

An Unbeatable

Music By Post Service.

Please send me by return of post a copy of the catalogue | enclose $£ \mid$ to cover postage and packing.

(please tick)
- A Compendium of Early Music
-Music for Recorders and
Historical Woodwind.
Music for the Organist.

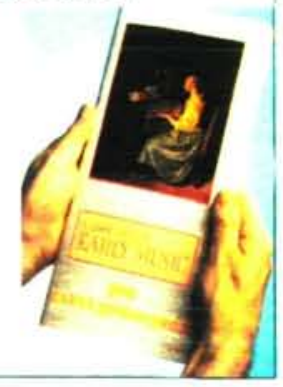

TEL NO 


\section{Monteverdi}

LIncoronasione di
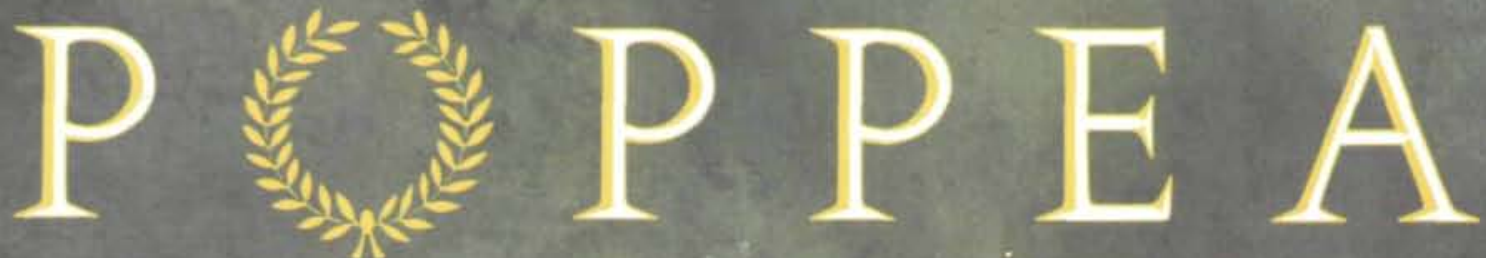

Arleen Auger Della Jones

Sarah Leonard

Linda Hirst

James Bowman

Gregory Reinhart

City of London Baroque Sinfonia

Riehard Hickox $3 \mathrm{MC}\left(\mathrm{CrO}_{2}\right) \mathrm{VCT} 790775-4$
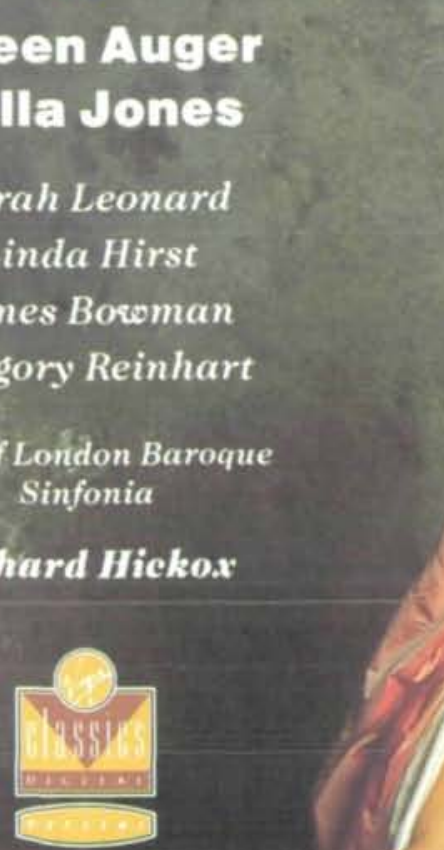
Carmina Burana Vols th \& IV New London Consor

Phitio Pickett

$2 \cos 4251172$

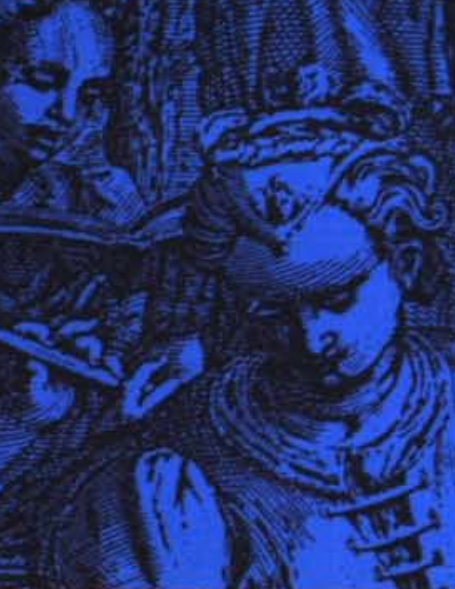

Haydn

Arias \& Cantatas Arleen Augér

Handel \& Haydn Society

Christopher Hagwood

CD 4254962 MC 4254964

\section{-}

6. Thilip Tiekert (19)
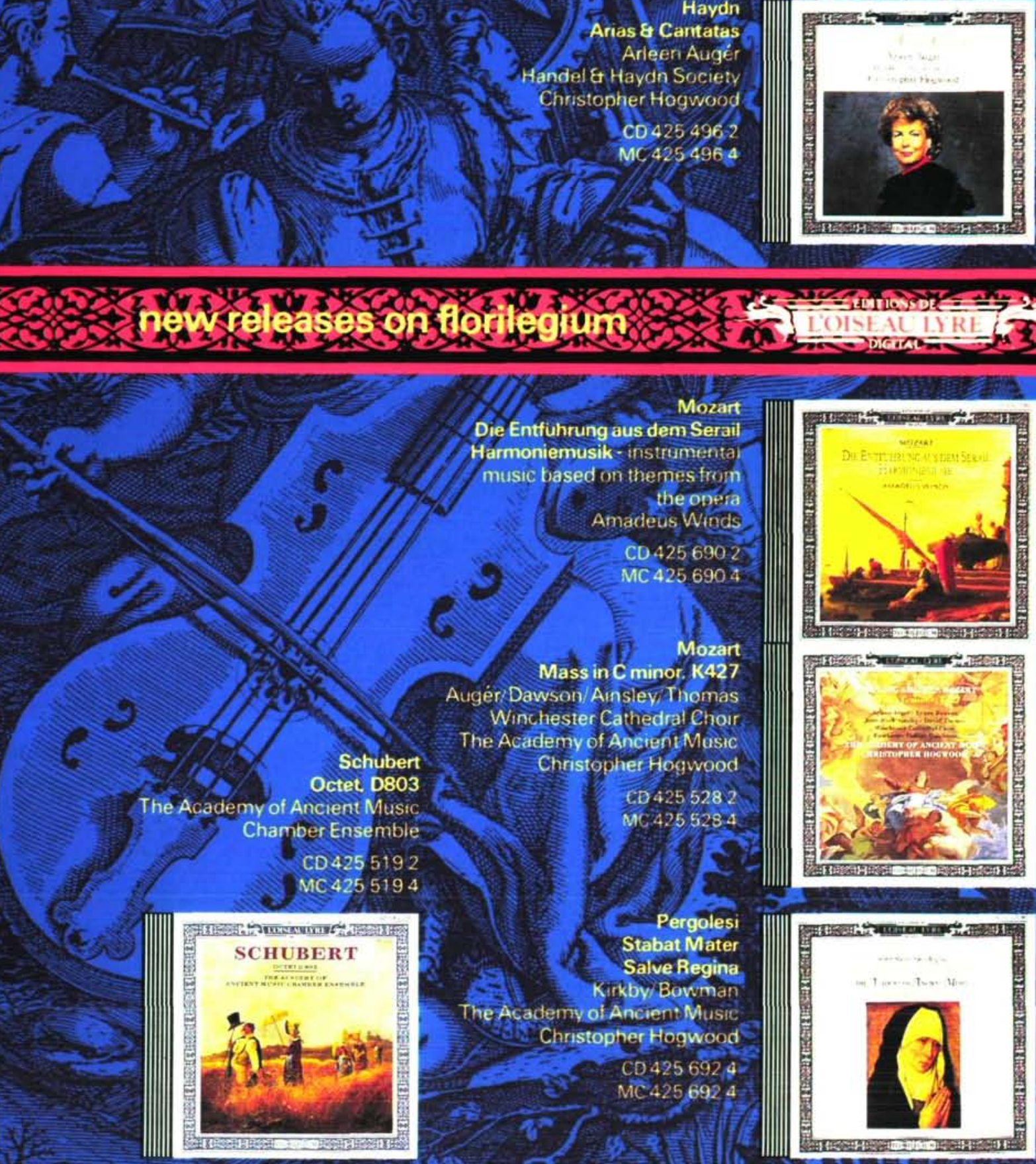

Die Entfuhrung aus dem Serail

Harmoniemusik - instrumenta)

music based on themes from

the onera

Amadeus Winds

$\mathrm{CD} 4256902$

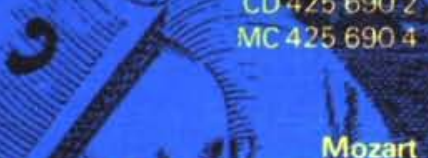

Mass in C minor. $\mathrm{K} 427$

Augér Dawson/Ainsley Thomas

Winchester Cathedral Choir

The Academy of Ancient Music

Christopher Hogwood

C. 4255282

MC 4255284

송

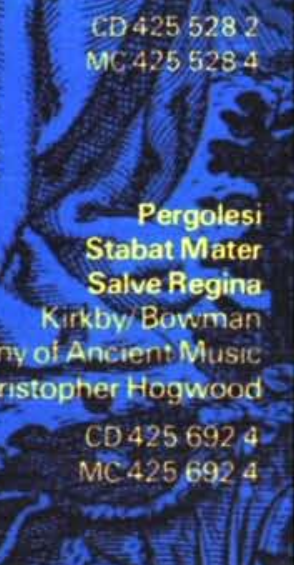

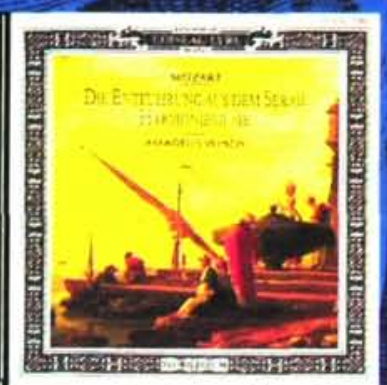
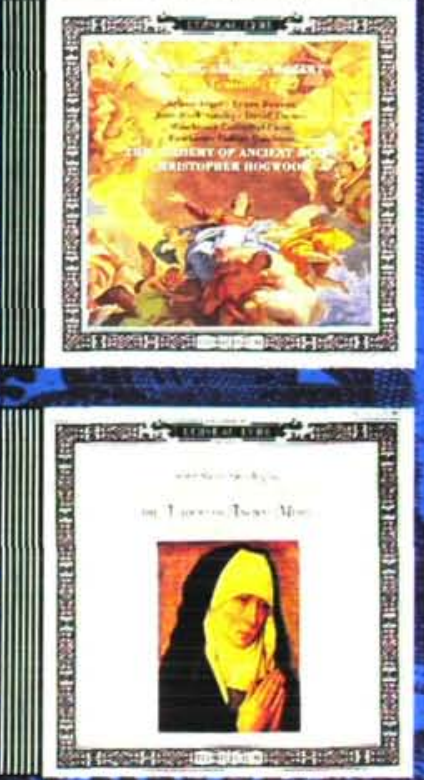